\title{
Towards sustainable charcoal production and trade in Baringo County
}

Mieke Bourne', Phosiso Sola', Mary Njenga', Grace Koech', Moses Kirimi', Siko Ignatius', Erick Otieno

\section{Key messages}

- Woodfuel, particularly charcoal, is an important energy source in urban areas and a livelihood source in rural areas.

- Actors in the Baringo-Nairobi charcoal value chain get between KES 107 and 613 per bag of charcoal depending on their location and role.

- In most parts of Baringo County, charcoal is produced from the invasive species Prosopis juliflora (mathenge, also known in some countries as 'mesquite').

- Community members, stakeholders and county officials identified priorities for the production and governance of the mathenge charcoal value chain.

- Strategies include proper management of biomass, efficient processing and effective utilization, and adequately regulated and supported value chains from production to consumption.

- Good governance of woodfuel value chains will only be achieved when there are transparent, consistent and coordinated regulatory institutional mechanisms that support and incentivize compliance and penalize illegality along the whole value chain. The County Environment Committee initiated a governance process, whilst community members have been engaged in sustainable mathenge charcoal production in Marigat Sub-county.

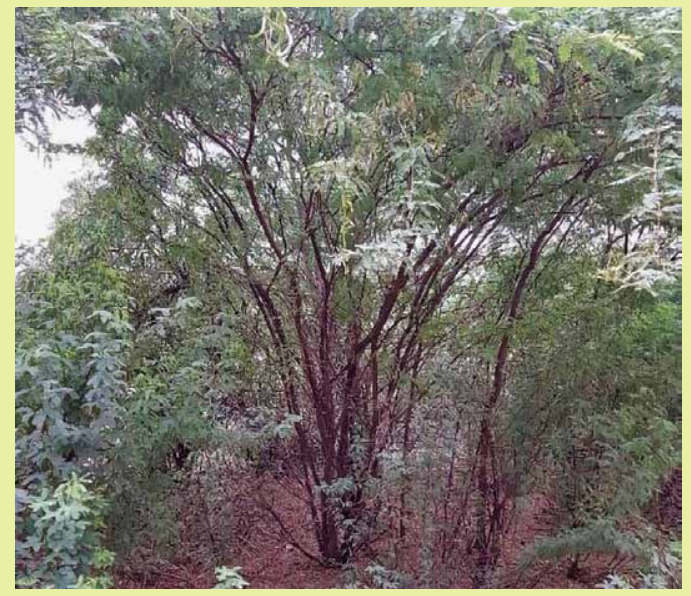

Figure 1. Prosopis juliflora.

Photo: Phosiso Sola/World Agroforestry

\section{Woodfuel situation in Kenya}

Woodfuel is of critical importance for millions of households in rural and urban Kenya. Charcoal is the most preferred and affordable form of energy in urban areas. It is used by $86 \%$ of households in Nairobi, with $43 \%$ having charcoal as their primary energy source (Ndegwa et al. forthcoming). While charcoal is important both as an energy and livelihood source, its legality has been in limbo under the logging moratorium of 2018 extended to November 2020, with a ban on its movement but not its production and use.

1 World Agroforestry (ICRAF)
Thus, charcoal production continues with no licensing, support or guidance. As long as only "three" bags are being sold along the roadside, it is termed local production. And yet, huge markets in the city centers still need to be supplied. Charcoal production has been associated with the clearing of indigenous trees and land degradation, particularly in the arid and semi-arid regions of the country, as well as causing health problems for the consumers. In Baringo the story is different, as charcoal is largely produced from the invasive Prosopis juliflora.

To enable a sustainable woodfuel value chain in the country, a couple of issues must be addressed: i) proper management of biomass, efficient processing and effective utilization, and 


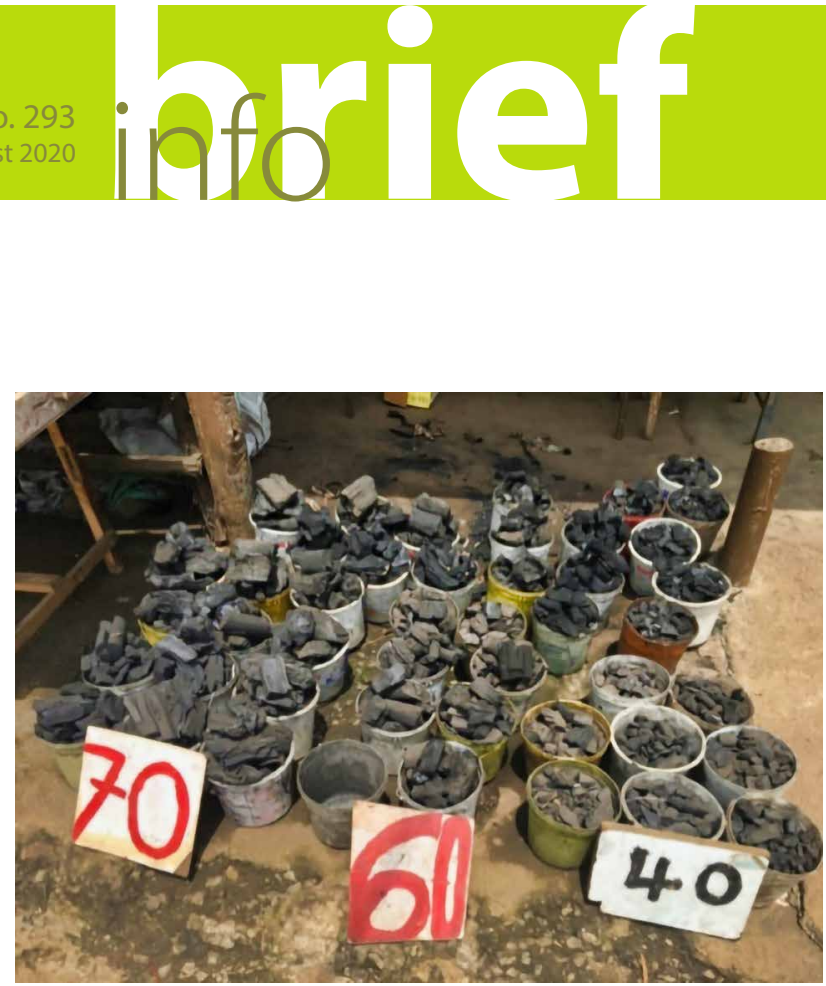

Figure 2. Charcoal at retail points in Nairobi. Photo: Mary Njenga/World Agroforestry

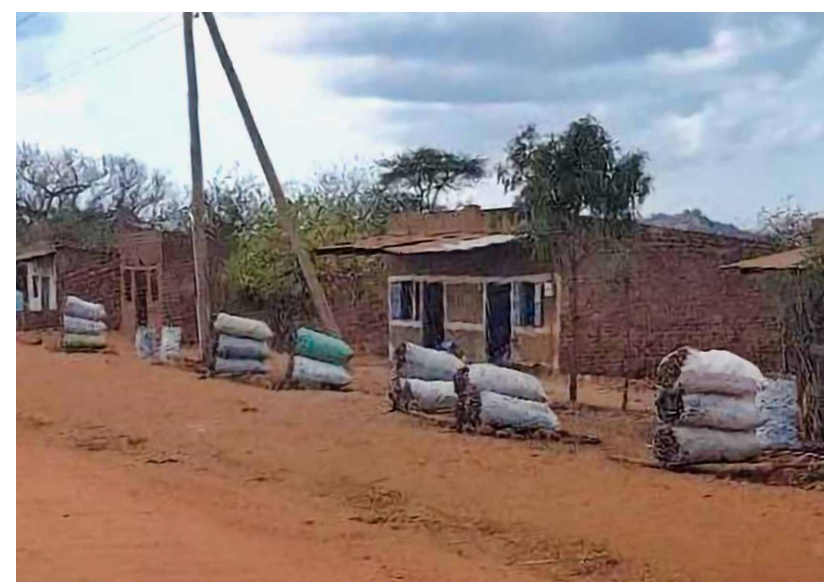

Figure 3. Charcoal bags on the roadside in Kitui rural sub-county.

Photo: Phosiso Sola/World Agroforestry

ii) well-regulated and supported value chain from production to consumption systems. In the last 18 months, World Agroforestry (ICRAF) and partners undertook a number of activities in Baringo County and Kenya in general to generate evidence on the potential for developing sustainable woodfuel value chains, including through community and stakeholder engagement processes. This is under the European Union-funded project entitled Governance of Multifunctional Landscapes (GML) in Sub-Saharan Africa with a component on knowledge, policy options and engagement for more sustainable woodfuel value chains. This policy brief summarizes the key interventions under the project.

\section{Charcoal value chain}

A critical review of the Kenyan woodfuel and trade flows analysis survey indicated that woodfuel, particularly charcoal, is produced

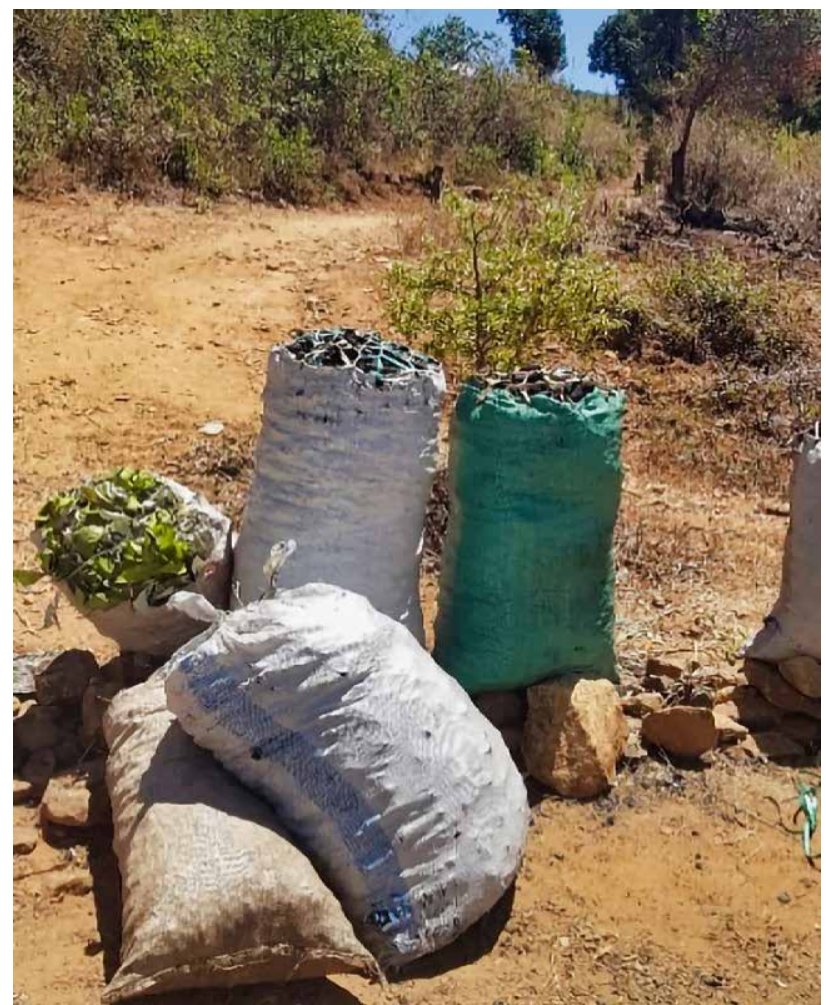

Figure 4. Charcoal bags on the roadside in Marigat Subcounty Baringo.

Photo: Phosiso Sola/World Agroforestry

in rural areas and that most of the wood is sourced from private farms (Ndegwa et al. 2020). However, many landowners (65\%) did not undertake any management practices to enhance tree regeneration and growth. Women were restricted to the tail ends of the value chain, for instance, they constituted $57 \%$ of retailers (Ndegwa et al. 2020). The study concluded that charcoal remains an important energy, livelihood and income source in Baringo and Kenya in general, and thus there is a need to invest in making woodfuel value chains green, sustainable and competitive. A value chain survey conducted in 2018 indicated that almost all (97\%) households involved in charcoal production mainly used traditional earth mound kilns (Ndegwa et al. forthcoming). Improvements in the nature, processes and technologies employed during production are crucial if unnecessary tree cutting is to be reduced. Thus, capacity development of charcoal producers is a key intervention towards achieving sustainable charcoal production.

Main income sources for charcoal producers in Baringo County were crop, charcoal and livestock production (Figure 5). For this reason, this policy brief focuses on charcoal rather than other woodfuel value chains. Most of the charcoal from Baringo was sold in urban centers and as far away as Nairobi. The Baringo-Nairobi supply chain had brokers as some of the key actors based in Nairobi (Figure 6). Incomes and profits were concentrated in the center of the value chain. The transporters' gross margin accounted 


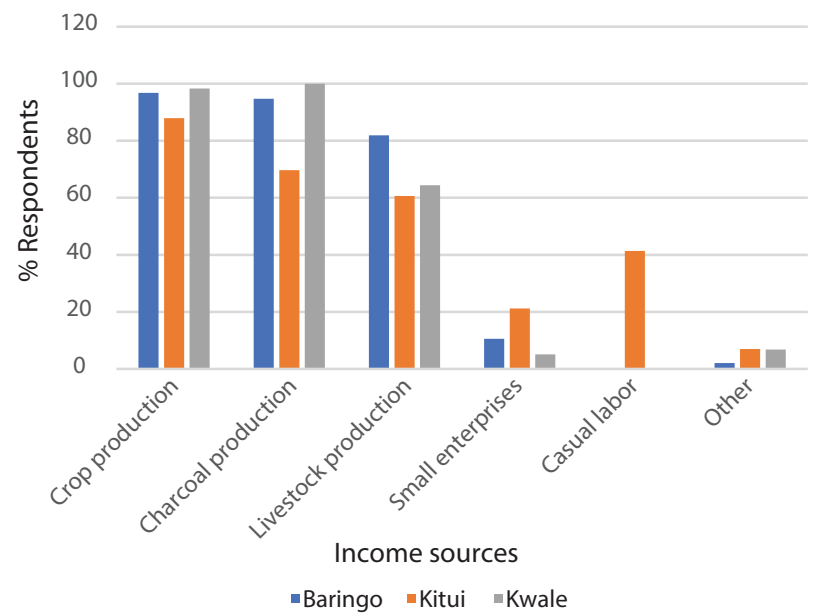

Figure 5. Major income source for charcoal producers.

for the largest share of the final price, at 47\% when charcoal is sold in bags or $39 \%$ when it is sold in tins, whereas producers only realized gross margins of 18\%. The transporters also had the largest net income per bag of KES 613, while producers made KES 318 per bag. Even then, this was still a significant livelihood source, making up over $50 \%$ of the household income for producers.

\section{Exploring the potential of sustainable charcoal production in Baringo County}

The major species used for charcoal production in Marigat Subcounty in Baringo is Prosopis juliflora (mathenge), an invasive tree species that was introduced in Baringo County in the 1980s to address desertification (Figure 7). Since its introduction, mathenge has spread across the county at a rate of 640 hectares per year (Mbaabu et al. 2019), leading to the degradation of pasture, woodlands and human settlements. Participatory mapping
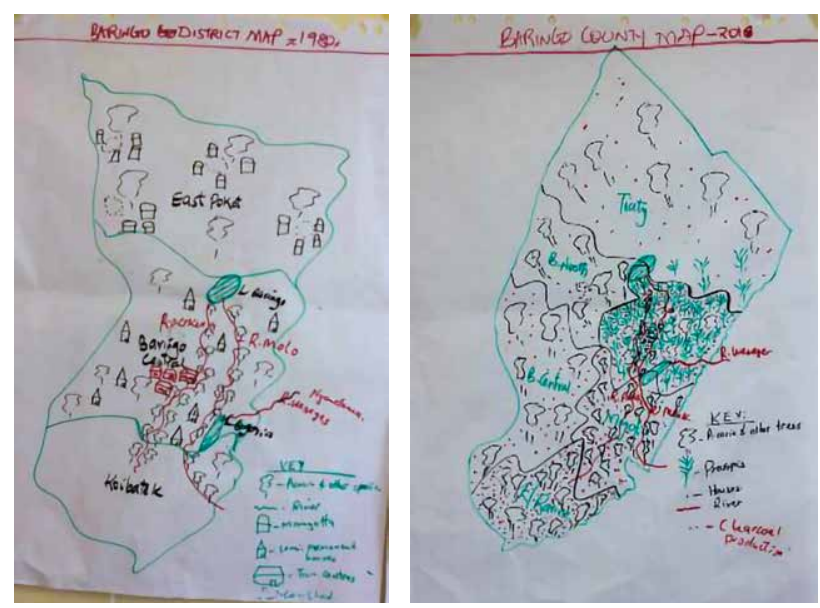

Figure 7. Participatory maps showing Baringo County before (left) and after (right) the introduction of mathenge.

exercises during a stakeholder engagement workshop in October 2018 suggested a similar trend in the expansion of mathenge.

Community Visioning and Action Planning (CAP) meetings were conducted in Loboi, Ilchamus and Ng'ambo locations in Marigat Sub-county in June 2019 (Figure 8). A total of 160 (102 men and 58 women) community representatives were involved in identifying and prioritizing capacity needs for sustainable woodfuel management. The continuous spread of invasive mathenge was said to have both negative and positive impacts on each community's livelihoods. However, the communities envision a situation where, by 2030, the mathenge invasion will be under control in the heavily invaded Marigat Sub-county through the implementation of prioritized interventions on management by utilization (Table 1). Men and women separately ranked charcoal as the number one product from managing mathenge among the 14 products identified during the community workshops (Njenga et al. 2019). However there were a number of challenges associated with this livelihood activity (Table 1).

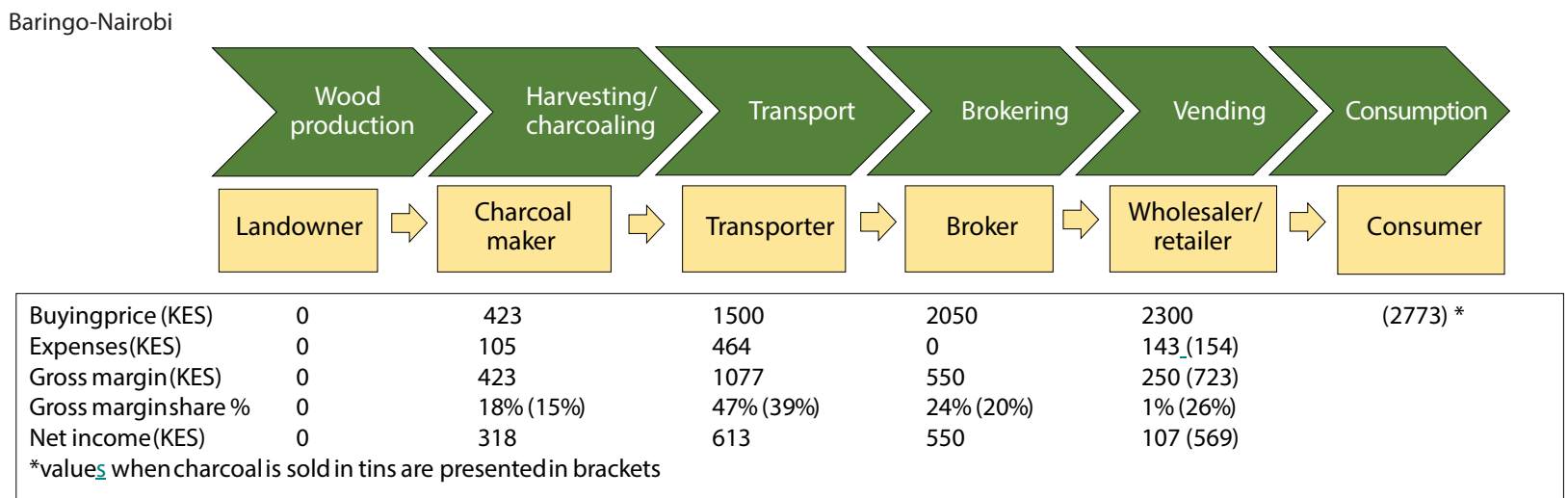

Figure 6. Schematic representation of Baringo-Nairobi charcoal value chain. 


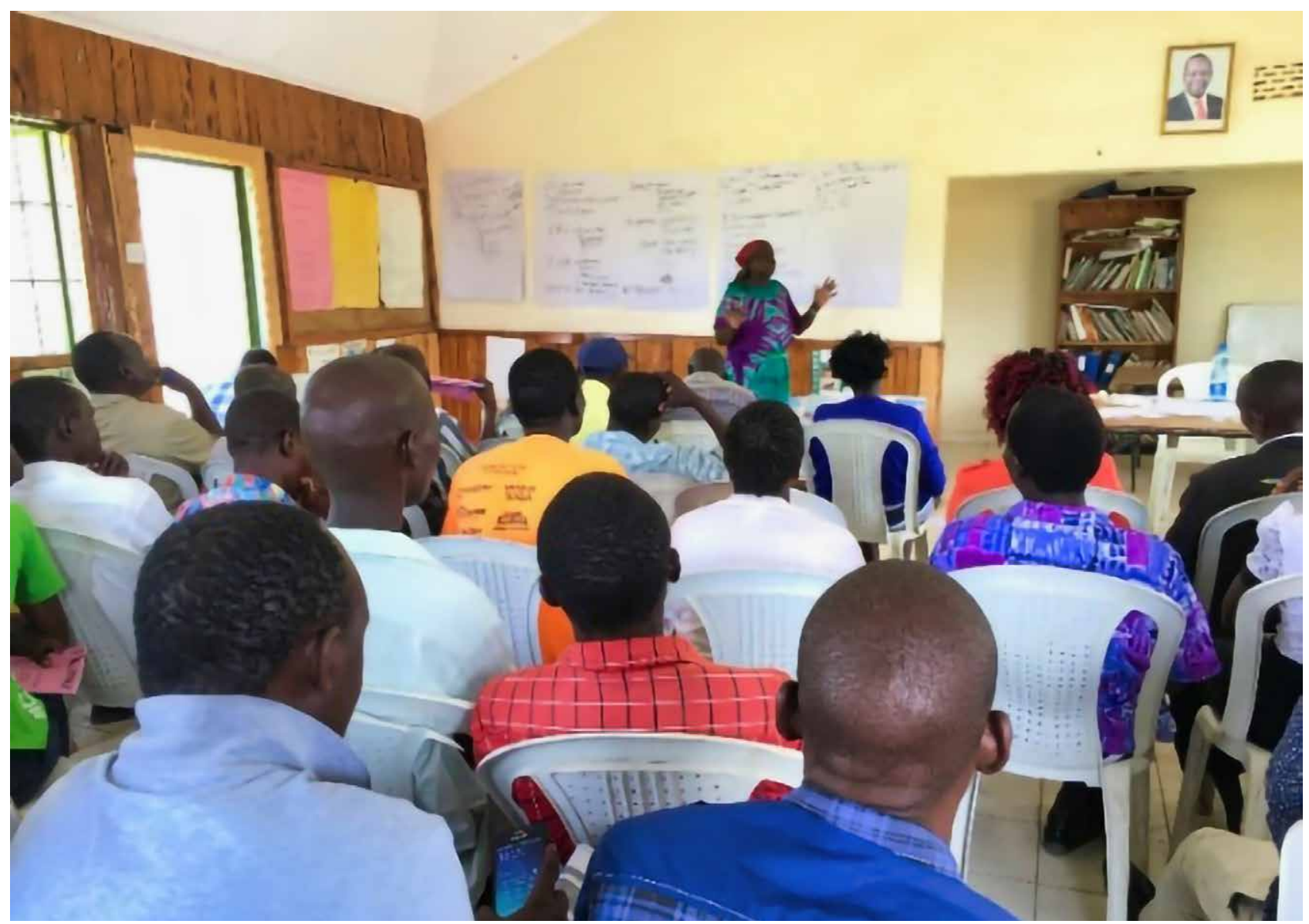

Figure 8. Community members participating in the CAP process in Marigat Sub-county. Photo: Erick Wanjira/World Agroforestry

\section{Table 1. Priority interventions Prosopis juliflora management by utilisation and associated challenges}

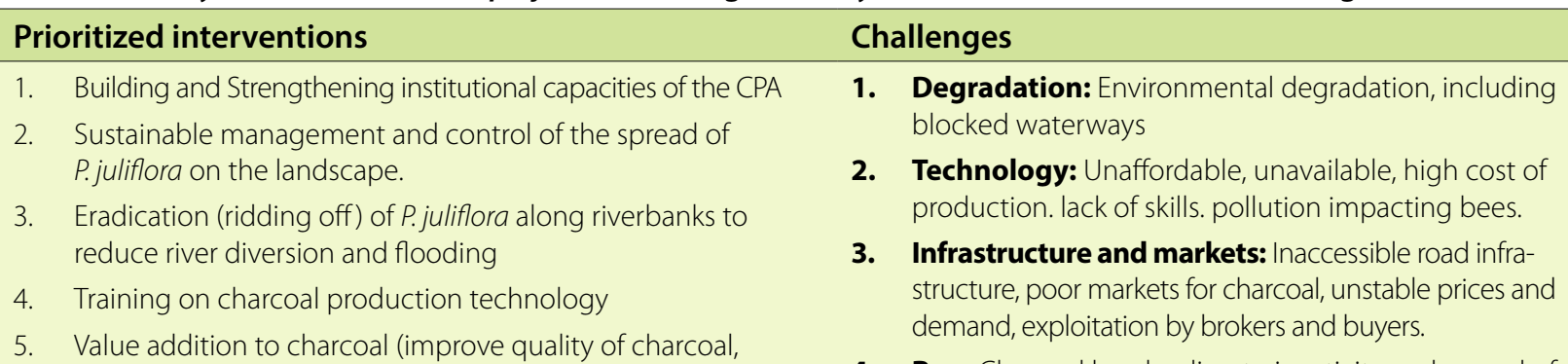
branding and packaging, advertisement)

6. Construction of more feeder roads by the government to ease movement of charcoal to market

7. Lift on Charcoal Ban and issue permit in P. juliflora areas for charcoal production

8. Charcoal price Control: -All stakeholders be fully involved for better prices.

9. Government policy, regulation and enforcement: Review and Awareness creation

10. Community by-laws/rules including rules on child labor in charcoal production

4. Ban: Charcoal ban leading to inactivity and spread of mathenge in the landscape. School drop-outs due to loss of income.

5. CPAs: Lack of accessible and safe charcoal collection centers within the location; dormant or inefficient charcoal producer associations.

6. Regulation: Unnecessary bureaucracy around charcoal production inhibits management of mathenge.

7. Alternatives: Competition from other energy sources, e.g. liquid petroleum gas.

8. Corruption and discrimination. 


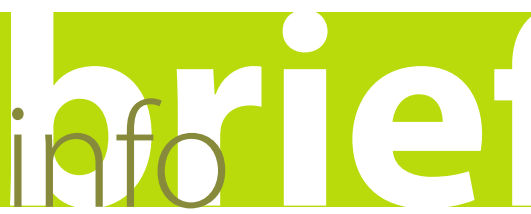

No. 293

August 2020

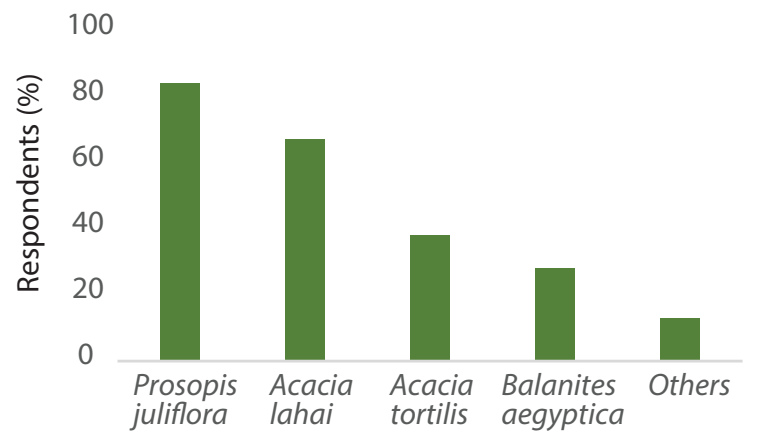

Figure 9. Main tree species preferred for charcoal production in Baringo County.

Mathenge is the main source of wood for charcoal production in Baringo County. The survey conducted indicated that more than $80 \%$ of producers used mathenge while a significant proportion (67\%) preferred the indigenous Acacia tortilis (Ndegwa, forthcoming; Figure 9).

Priority interventions identified by the community include:

i) Train the community in modern charcoal production technology and make it accessible and affordable.

ii) Build and strengthen the institutional capacities of charcoal producers associations (CPAs) to enable them to deliver on their responsibility in a more effective and efficient way as per the existing regulations.

iii) Train the communities in ways of managing and controlling the spread of mathenge that are not only sustainable but also affordable.

iv) Add value to the Baringo County charcoal (such as branded packaging).

v) Lift the ban on charcoal.

vi) Establish tree nurseries to enhance planting of highvalue tree species on lands where mathenge has been uprooted, among other interventions.

\section{Promotion of improved technologies and practices for charcoal production}

One of the objectives of the GML project is to pilot activities in order to improve charcoal production practices. A training of trainers (ToT) session was held in October 2019 for 32 people (21 men and 11 women) of whom 24 were charcoal producers. The improved earth mound kiln and drum kiln (Figures 10 and 11) were used in the training as they are simple and affordable technologies with higher recovery efficiencies of $27 \%$ and $30 \%$, respectively (Oduor et al. 2006). Five artisans were trained to create the improved kilns. The trainers who attended the ToT session were trained in the appropriate management of mathenge, efficient charcoal processing including use of carbonizing tree residues for biochar and charcoal briquette production, effective

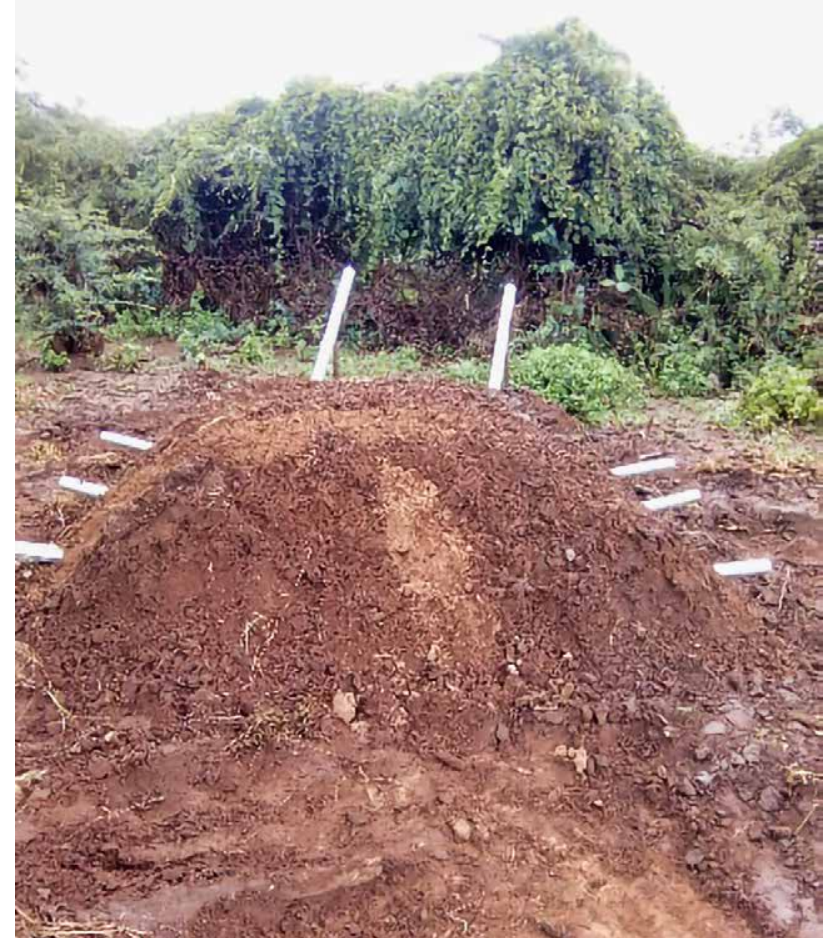

Figure 10. Improved earth mound kiln.

Photo: Moses Kirimi

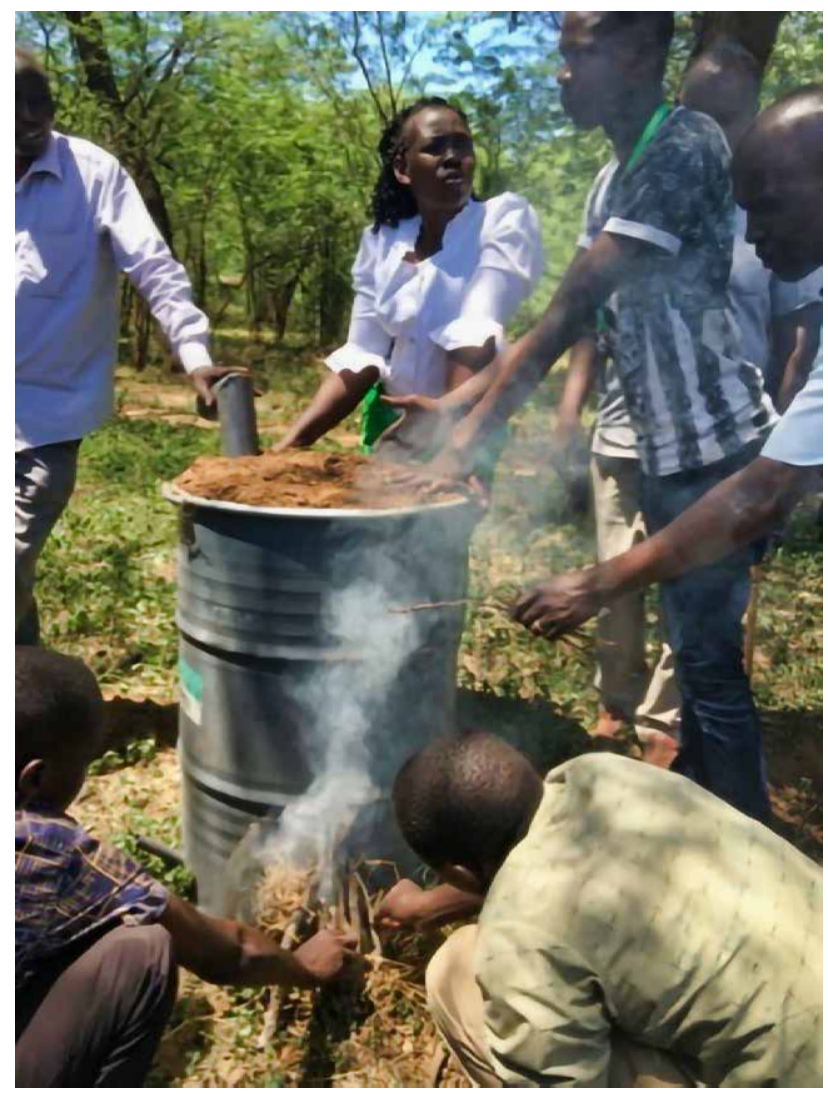

Figure 11. Drum kiln.

Photo: Mary Njenga 


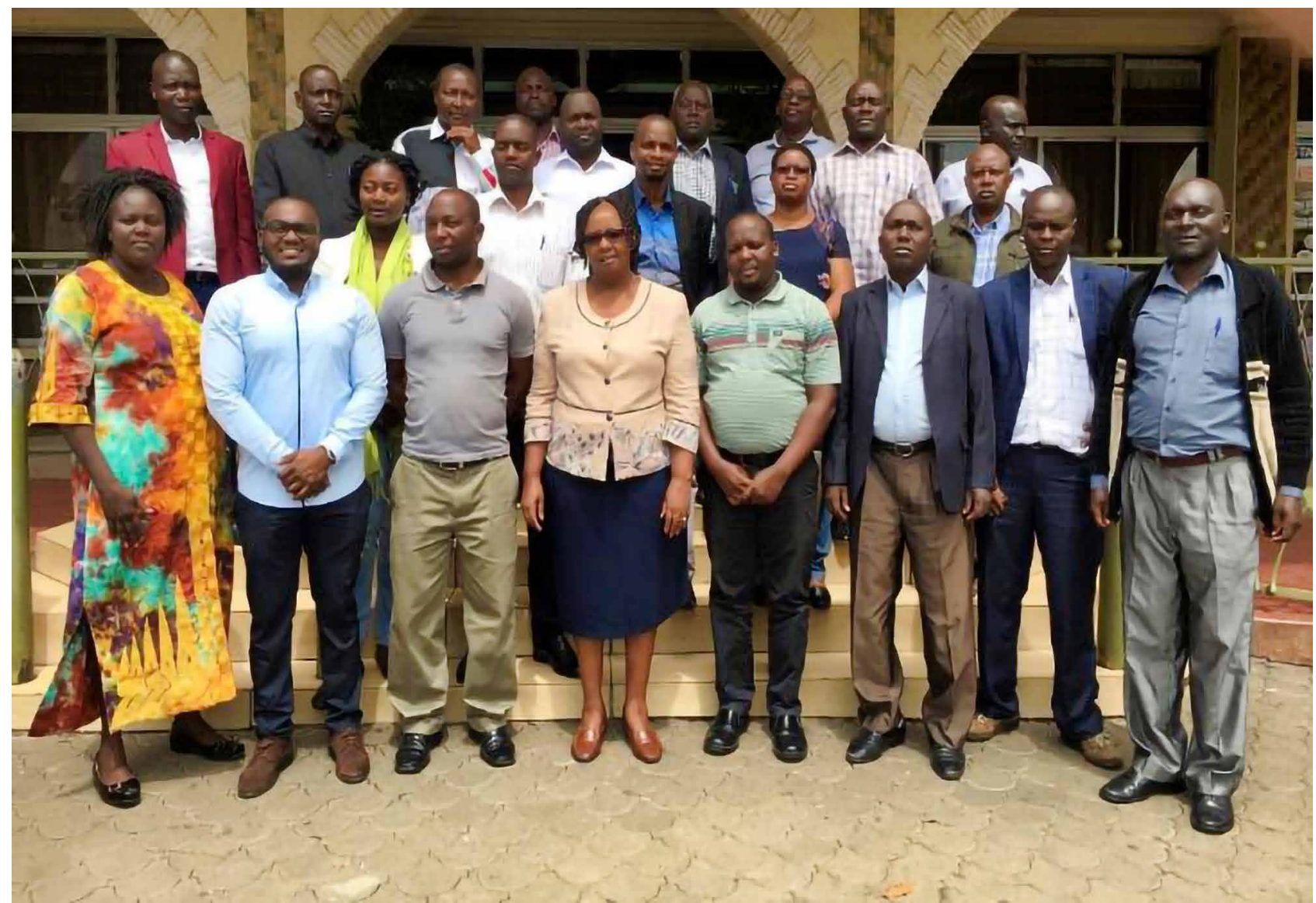

Figure 12. Participants of the Baringo County Environmental Committe meeting.

Photo: Joseph Chege

marketing, and trade and charcoal regulations. A participatory collaborative learning approach was adopted to catalyze farmer-tofarmer extensions targeting charcoal producers' associations (CPAs). Twenty-four charcoal producers were engaged in testing the kilns for their efficiencies and trying out the biochar for raising vegetable seedlings; they will be supported to transfer the knowledge and skills to the other 150 members of three CPAs.

In addition, charcoal producers and researchers participated in planned comparison trials using improved earth mound kilns, traditional earth mound kilns and drum kilns and found recovery rates/charcoal yields of original wood mass to be $22 \%$, $15 \%$ and $21 \%$, respectively (Njenga et al. forthcoming). This is a $50 \%$ increment in charcoal yield by using an improved kiln with simple modification of the traditional earth kiln, by drying wood well to below $20 \%$ moisture content, stacking wood tightly to reduce air spaces and allow heat transfer, appropriate monitoring, and fixing six breathers and two chimneys (Njenga 2020). The drum kiln enhances use of tree residues otherwise considered as waste after charcoal production. The tree residues produce additional charcoal as well as charcoal fines for biochar or briquette production. Use of improved carbonization technologies reduces cutting of trees, increases producer incomes and ultimately reduces resultant greenhouse gas emissions during charcoal carbonization.

Notwithstanding, a survey on technology adoption, completed in 2019 (Siko 2019), using a choice experiment with charcoal producers in Baringo found that they were not willing to pay more for improved kilns given the capital outlay and expertise required; however, they were willing to invest or pay more for improving their wood quality for better mathenge charcoal. They preferred less tedious technologies/processes (26\%), that produce quality charcoal (24\%) and are affordable (22\%). Therefore, local production of improved kilns should be supported to ensure they are readily available, easy to use and cheap, if the producers are to use them.

\section{Woodfuel governance in Baringo County}

A woodfuel governance assessment was undertaken summarizing the legal frameworks and institutional arrangements 
for production and trade in charcoal. Charcoal production and trade have been and still are managed under the national government forestry legislation, especially the Charcoal Rules of 2009. However, with devolution in 2013 , county governments have developed strategies to guide and control this value chain. Likewise, the Baringo County has enacted the Charcoal Product Act 2016, although it has not yet been implemented. To compound the situation, while the current logging moratorium does not allow for commercial charcoal production, subsistence production on private land is permitted. In addition, no movement permits have been granted, making sale of more than three bags illegal. This governance framework legalizes some parts of the value chain (retail and consumption) and criminalizes others (commercial production and transportation), ignoring the interconnectedness and interdependence among the actors and thereby making charcoal 'illegally legal'.

The exception applied to Prosopis juliflora (mathenge) changes the discourse in Baringo and other impacted counties, as it allows production and trade of mathenge charcoal upon meeting certain conditions. A policy engagement workshop with the Baringo County Environment Committee was held in October 2019 to discuss the mandate of the committee on charcoal production and trade amid the national ban on logging as well as deliberating on the report of the Baringo Prosopis Charcoal Exemption Taskforce. The committee learnt that the taskforce had already presented the report to the Cabinet Secretary for Environment and Forestry. A county roadmap for formalizing the Prosopis value chain was initiated. However, results from a stakeholder network analysis conducted in 2018 for regulators and value chain actors suggested that most stakeholders had multiple and at times contradictory roles, such as regulation and production. The need to reduce duplication is particularly important as many of the enforcement roles historically played by Kenya Forest Service (KFS) are expected to transition to the counties. Additionally, CPAs and other community-based and conservation stakeholders have played an important role in linking service providers to the community and should be engaged in processes of making woodfuel value chains sustainable.

\section{Opportunities for a sustainable mathenge value chain in Baringo County}

\section{Exemption of Prosopis juliflora (mathenge) from logging moratorium of 2018}

1. The current process of developing safeguards for the Prosopis juliflora exemption by the taskforce is awaiting ministerial approval.

2. Development of the Baringo roadmap to implement safeguards including the Baringo Charcoal Production Act.
3. Wider stakeholder engagement for codesigning the roadmap for a sustainable mathenge charcoal value chain development in the county should be encouraged.

4. Ongoing streamlining of roles and responsibilities between national and county governments as part of the transitional implementation plans (TIPS) for the support and regulation of the charcoal value chain requires attention.

\section{Prosopis management by utilization}

5. Well-managed mathenge can offer opportunities as a sustainable and low-cost source of biomass feedstock for charcoal and biochar production for fuel and soil improvement respectively.

6. Mathenge charcoal, produced from improved and appropriate technologies will reduce pressure on indigenous woodlands and open up invaded areas for natural regeneration of indigenous woodlands, grazing lands and cultivation of food crops in agroforestry systems.

7. Together with charcoal production, integrated approaches offer opportunities to reduce the extent of mathenge invasion.

\section{Formalized mathenge charcoal value chain}

8. CPAs and communities could be further strengthened in the management and utilization of mathenge using appropriate techniques, including building capacity for production and utilization of affordable and efficient kilns to enhance recovery and reduce waste and pollution.

9. Support marketing of and trade in mathenge charcoal.

10. Brand and promote sustainable mathenge charcoal to supply urban centers.

\section{Acknowledgments}

This project is implemented with the generous support of the European Union through the Governing Multifunctional Landscapes (GML) in Sub-Saharan Africa project, implemented by the Center for International Forestry Research (CIFOR) in partnership with World Agroforestry (ICRAF), the Deutsche Gesellschaft für Internationale Zusammenarbeit (GIZ), the Forest and Farm Facility (FFF), the Food and Agriculture Organization of the United Nations (FAO), and national and local organizations. We are also grateful for the support received from the CGIAR Program on Forests, Trees and Agroforestry (FTA) and Water Land and Ecosystems (WLE) - Sustaining Rural-Urban Linkages.

\section{References}

Mbaabu P, Ng W-T, Schaffner U, Gichaba M, Olago D, Choge S, Oriaso S and Eckert S. 2019. Spatial evolution of Prosopis invasion and its effects on LULC and livelihoods in Baringo, Kenya. Remote Sensing 11:1217. http://dx.doi.org/10.3390/ rs11101217 
Ndegwa G, Sola, P., liyama M, Okeyo I, Njenga M, Siko I., Muriuki, J.2020. Woodfuel value chains in Kenya: a 20-year synthesis. Working Paper number 307. World Agroforestry, Nairobi, Kenya. DOl http://dx.doi.org/10.5716/WP20026.PDF

Ndegwa G, Sola P, Siko I, Kirimi M, Wanjira EO, Koech G and liyama M. forthcoming. Charcoal Value Chains in Kenya: the actors and trade flows

Njenga M. 26 April 2020. Transforming Kenya's invasive 'mathenge' bushes into charcoal farms. Widely considered a nuisance, the shrub is now a sustainable bioenergy option. Forests News. Bogor, Indonesia: Center for International Forestry Research (CIFOR). https://forestsnews.cifor. org/65644/transforming-kenyas-invasive-mathenge-bushesinto-charcoal-farms?fnl=en

Njenga M, Kirimi M, Koech G, Otieno E and Sola P . 2019. Training of trainers (ToT) on sustainable Prosopis Juliflora woodfuel production and utilization in Baringo County, Kenya Bogor, Indonesia: Center for International Forestry Research (CIFOR). https://www2.cifor.org/wp-content/uploads/ sites/38/2019/11/ToT\%20Sustainable\%20Woodfuel\%20 Baringo\%209-11\%200ctober\%202019\%20V2.pdf

Oduor N, Githiomi J and Chikamai B. 2006. Charcoal production using improved earth, portable metal, drum and Casamance kilns. Nairobi, Kenya: Kenya Forestry Research Institute (KEFRI). Siko I. 2019. Assessment of sustainable charcoal production in Kenyan Drylands: A case of Marigat Sub County. [Master's thesis]. Nairobi: University of Nairobi. http://erepository.uonbi.ac.ke/ bitstream/handle/11295/107744/Omariba\%20lgnatius\%20 Siko\%20Final\%20thesis\%20.pdf?sequence=1

Brief prepared by Mieke Bourne, Phosiso Sola, Mary Njenga, Grace Koech, Moses Kirimi, Siko Ignatius, Erick Otieno. June 2020. World Agroforestry

\begin{tabular}{|l|l|l|l|l} 
& $\begin{array}{l}\text { This research was carried out by CIFOR-ICRAF as part of the CGIAR Research Program on Forests, } \\
\text { Trees and Agroforestry (FTA). FTA is the world's largest research for development program to } \\
\text { enhance the role of forests, trees and agroforestry in sustainable development and food security } \\
\text { and to address climate change. CIFOR leads FTA in partnership with Bioversity International, } \\
\text { CATIE, CIRAD, INBAR, ICRAF and TBI. } \\
\text { FTA's work is supported by the CGIAR Trust Fund: cgiar.org/funders/ }\end{array}$ \\
PROGRAM on & $\begin{array}{l}\text { Forests, Trees and } \\
\text { Agroforestry }\end{array}$
\end{tabular}
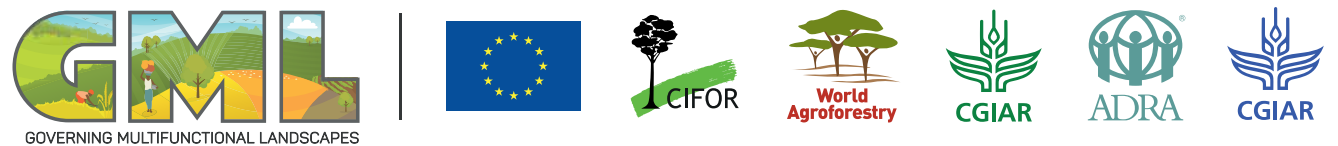

\section{cifor.org/gml}

\section{forestsnews.cifor.org}

